Rita Hvistendahl

Universitetet i Oslo

Glenn Ole Hellekjær

Universitetet i Oslo

Jon Magne Vestøl

Universitetet i Oslo

DOI: http://dx.doi.org/10.5617/adno.5545

\title{
Acta Didactica Norge 2007 - 2017
}

\section{Sammendrag}

Acta Didactica Norge ble etablert som fritt tilgjengelig tidsskrift for fagdidaktikk og lererutdanning på nivå 1 i 2007 etter initiativ fra Institutt for lcererutdanning og skoleforskning ved Universitetet i Oslo. Det var det første norske tidsskriftet som tok $i$ bruk tidsskrifts- og publiseringssystemet Open Journal Systems. I denne artikkelen trekkes det opp noen linjer i tidsskriftets tiårige historie fra etableringen i 2007 gjennom tre faser: oppstart, konsolidering og ekspansjon. Tidsskriftet er $i$ dag et tidsskrift på publiseringstjenesten FRITT - frie tidsskrifter fra UiO. Det tar verken abonnements- eller publiseringsavgift. Tidsskriftet har hatt en kraftig vekst i antall artikler fra starten til i dag, og et høyt antall nedlastinger tyder på at det når ut til en stor leserskare.

Acta Didactica Norge 2007 - 2017

\begin{abstract}
In 2007 Acta Didactica Norge, an open-access, level 1 journal for subject didactics and teacher education, was established at the initiative of the Department of Teacher Education and School Research, the University of Oslo. It was the first Norwegian journal to use the Open Journal Systems for online journals. This article provides an overview of the first ten years, through the start-up, consolidation, and expansion phases. Today Acta Didactica Norge is one of Oslo University's FRITT journals, which does not require subscription or publication fees. FRITT is an Open Access journal publishing service hosted by the University Library. During the last ten years the journal has had a dramatic increase in submitted and published articles and a high number of downloads give evidence of a wide readership.
\end{abstract}




\section{Et nytt norsk fritt tilgjengelig tidsskrift}

Den 4. oktober 2007 ble den første utgaven av tidsskriftet Acta Didactica Norge utgitt. Det var det første tidsskriftet i Norge som tok i bruk Open Journal Systems (OJS), et tidsskrifts- og publiseringssystem utviklet av Public Knowledge Project ved University of British Columbia med det formål å utvide og bedre tilgangen til forskning, og det var det første vitenskapelige tidsskriftet i Norge for fagdidaktikk og lærerutdanning.

Acta Didactica Norge har helt fra starten av vært et Open access-tidsskrift som gir fri tilgang online til forskningsresultater. I tillegg til at artiklene i tidsskriftet kan brukes fritt, er det også kostnadsfritt for forskere å publisere i tidsskriftet. I 2007 fantes det enkelte andre norske tidsskrift som ble publisert på nettet, og noen tidsskrift som verken tok abonnements- eller publiseringsavgift, men ingen av dem brukte Open Journal Systems. Ved å ta dette publiseringsverktøyet i bruk har Acta Didactica Norge vært et pionertidsskrift. Ved hjelp av OJS er tidsskriftet heldigitalt: Utgavene blir fritt publisert på nettet alene, det foreligger ingen papirutgaver. Innsending av artikler, fagfellevurdering og annet skriftlig redaksjonelt arbeid blir utført i OJS og følger saksgangen på denne plattformen. Artiklene publiseres og arkiveres på tidsskriftets nettside og kan leses fritt og videresendes digitalt derfra.

Det fantes i 2007 pedagogiske tidsskrift som publiserte artikler med relevans for lærerutdanning, og et nytt tidsskrift for naturfagdidaktikk, NorDiNa, utkom i 2005. Acta Didactica Norge fylte et noe annet behov enn de eksisterende tidsskriftene ved at det tok mål av seg til å bli et vitenskapelig tidsskrift for hele det fagdidaktiske feltet, både for de enkelte allmennfagenes og yrkesfagenes didaktikk, og for lærerutdanning. Som sådan var tidsskriftet Norges første.

\section{Etablering og drift}

Initiativet til tidsskriftet ble tatt fra daværende Institutt for lærerutdanning og skoleutvikling, nå Institutt for lærerutdanning og skoleforskning (ILS), ved Det utdanningsvitenskapelige fakultet, Universitetet i Oslo (UiO). Instituttet utga fra 2000 en skriftserie, først papir- så nettbasert, under navnet Acta Didactica. Fra høsten 2006 hadde instituttet en prosjektgruppe i arbeid under ledelse av Karl Henrik Flyum for å forberede etableringen av et tidsskrift. I gruppen deltok representanter fra de fagdidaktiske miljøene ved NTNU, Universitetet for miljøog biovitenskap, Universitetet i Bergen og Universitetet i Tromsø. Arbeidet inngikk i prosjektet «Aiding Scientific Journals Towards Open Access Publishing» finansiert av NordBib 2006-2009, som var et program under NordForsk, Nordisk Ministerråd for å støtte og utvikle initiativ til Open accesspublisering. OJS-programvaren var gratis forutsatt ikke-kommersiell bruk. Flyum oversatte den til norsk, og med det fikk man et nytt og gratis norskspråklig publiseringsverktøy utviklet for vitenskapelige nettidsskrift. Det 
arbeidet som ble lagt ned i oversettelsen av OJS, kom også framtidige norske tidsskrift som tok verktøyet i bruk, til gode.

Den 15. mars 2007 gikk det ut en invitasjon fra ILS undertegnet av assisterende instituttleder Geir Knudsen og prosjektleder Flyum til et arbeidsmøte i Oslo den 18. april samme år (ILS, Møteinvitasjon 15.3.2007). Invitasjonen ble sendt de samarbeidende universitetene og Høgskolene i Akershus, Bergen og Oslo. På møtet ble det konstituert et redaksjonsråd med medlemmer fra de samarbeidende institusjonene med Ove Haugaløkken ved NTNU som leder. Det ble utpekt en midlertidig tidsskriftredaksjon med Rita Hvistendahl som ansvarlig redaktør, Karl Henrik Flyum som redaksjonsleder og layoutredaktør og Therese Nerheim Hopfenbeck og Jon Magne Vestøl som redaktører, alle fra ILS. Redaksjonen, som ble konstituert den 3. mai, skulle påta seg ansvaret for etableringen av tidsskriftet og driften det første året. Tidsskriftet fikk navnet Acta Didactica Norge for å skille det fra skriftserien, som i 2009 skiftet navn til Acta Didactica Oslo. Etter at det ble avklart at tidsskriftet ikke kunne bruke en nettadresse med UiO i navnet, ble domenenavnet adno.no kjøpt, og det ble åpnet for innsending av artikler til fagfellevurdering.

I Kunngjøring og invitasjon fra ILS til NRLU den 7. mai 2007 begrunnes behovet for tidsskriftet, og et ambisiøst mål for virksomheten slås fast:

Tidsskriftet henvender seg først og fremst til alle som har ansvar for å utføre fagdidaktisk forsknings- og utviklingsarbeid ved lektor- og lærerutdanningene i Norge. Dette faglige feltet har hittil manglet en egen felles vitenskapelig publiseringskanal her til lands, men med det nye tidsskriftet blir elektronisk publisering tatt i bruk for å bøte på mangelen. Tidsskriftet tar mål av seg til å bli landets viktigste faglige forum for forsknings- og utviklingsdokumentasjon og kvalitetsutvikling på sitt felt.

I argumentasjonen for tidsskriftet legges det først og fremst vekt på behovet for en publiseringskanal for fagdidaktisk forskning. Behovet for å øke den vitenskapelige publiseringen ved lærerutdanningsinstitusjonene ble understreket ved innføringen av det såkalte tellekantsystemet i 2005. Som grunnlag for tildeling av forskningsmidler til institusjonene ut fra vitenskapelig produksjon ble publiseringskanalene vurdert som tellende på to ulike nivåer, og etableringen av Norsk publiseringsindikator (NPI) i 2006 hadde som formål å fremme god forskning og skape oversikt over og innblikk i forskningsaktivitetene. Denne endringen $i$ finansieringen av universitets- og høyskolesektoren danner et bakteppe for etableringen av Acta Didactica Norge.

Videre i kunnjøringen understrekes det at tidsskriftet skal drives som et samarbeidstiltak mellom lærerutdanningsinstitusjonene, og at det skal finansieres med frivillige bidrag slik at det blir gratis for leserne. Når bortfall av abonnementsavgift gjennom fri tilgang til artiklene for institusjonene i liten grad framheves som argument for etableringen av tidsskriftet, kan det ha sammenheng med at finansieringen av tidsskriftet ikke var fullt avklart. Når det 
ikke nevnes at det var fritt å publisere i tidsskriftet, skyldes det nok at det å ta publiseringsavgift ikke var noen aktuell problemstilling i 2007 da det kun fantes noen ytterst få fritt tilgjengelige vitenskapelige tidsskrift i Norge.

ILS fortsatte å ha driften av Acta Didactica Norge. Istedenfor å satse på frivillige bidrag fra andre institusjoner vedtok instituttet å støtte tidsskriftet økonomisk (jf. ILS, Erklæring 18.05.07). Ansatte som bidro til redaksjonen av tidsskriftet eller til fagfellevurdering, fikk en godtgjøring i form av en prosentvis stillingsandel eller et timetall. Det ble bevilget en årlig sum til driften av tidsskriftet, og redaksjonelt arbeid i Acta Didactica Norge ble anerkjent som faglig relevant og meritterende ved instituttet. Denne praksisen har i hovedsak vært videreført siden, samtidig som tidsskriftet har invitert andre institusjoner til å bidra til det redaksjonelle arbeidet. Først i 2016 mottok tidsskriftet driftsstøtte fra Forskningsrådet etter søknad. Den tekniske driften av tidsskriftet på OJS ble ivaretatt av senioringeniør Torgeir Christiansen ved ILS inntil tidsskriftet i 2015 ble en del av FRITT - Frie tidsskrifter fra UiO ved Universitetsbiblioteket. Med denne innsatsen fra instituttet og fra Universitetsbiblioteket er tidsskriftet fortsatt fritt tilgjengelig og krever ingen abonnements- eller publiseringsavgift. Slike tidsskrift refereres i dag ofte til som platinum Open access-tidsskrift (beilsteinjournals.org; blog.scienceopen.com).

\section{Oppstartsfasen 2007-2009}

Etter at Acta Didactica Norge hadde publisert sin første utgave den 4. oktober 2007, bekreftet Norsk samfunnsvitenskapelig datatjeneste (NSD) den 31 . oktober samme år at tidsskriftet var registrert som ny kanal for vitenskapelig publisering på nivå 1 og skulle gis publiseringspoeng (jf ILS, Møtereferat 1.11.2007). Dette innebar at tidsskriftet oppfylte kriteriene for vitenskapelig publisering, det vil si at hver publisert artikkel hadde vært vurdert av to kvalifiserte fagfeller; at en vitenskapelig redaksjon hadde hatt ansvaret for manuskriptredigering, layout og korrektur; og at ingen institusjon stod for så mye som halvparten av de publiserte bidragene (UHR 2004).

Den første utgaven ble til i tidsrommet mellom arbeidsmøtet 18.4 .07 og publiseringen 4.10 .07 og inneholdt seks vitenskapelige artikler, en av dem registrert som invitert bidrag. I realiteten var alle artiklene invitert. Redaksjonen, som etter hvert ble utvidet med Else Askerøi fra Høgskolen i Akershus og Sylvi Penne fra Høgskolen i Oslo, henvendte seg direkte til forfatterne for å få fram artikler. Artiklene dekket et bredt tematisk spekter fra en diskusjon av begrepet fagdidaktikk, til læreplanen i KRL, rammeverket for PISA 2006, skoleprestasjonene til elever fra språklige minoriteter, praktisk tilnærming i fremmedspråkundervisningen og betydningen av kjønn, klasse og etnisitet for utdanningsvalg. To av artiklene var skrevet av doktorgradskandidater, den ene opprinnelig en prøveforelesning, de øvrige var skrevet av etablerte forskere. For å få inn artikkelbidragene og få dem vurdert av kvalifiserte fagfeller måtte redaktørene bruke sine respektive nettverk, for tidsskriftet var ennå ikke kjent i 
bredere kretser. Ikke bare redaksjonen, men også publiseringsverktøyet OJS besto prøven. Ansvarlig redaktør la vekt på at alt redaksjonelt arbeid skulle foregå på OJS-plattformen, og de som skulle bruke den, måtte læres opp i verktøyet.

Fra 2008 var tidsskriftet i ordinær drift. Til forskjell fra året før, ble artiklene ikke lenger samlet i en utgave, men publisert fortløpende etter hvert som de var vurdert av fagfeller, redigert og akseptert. Artiklene ble dermed publisert på forskjellige tidspunkt gjennom året. For artikler som ikke trengte omfattende omarbeiding, ble publiseringstiden kort. Totalt ble det publisert 8 vitenskapelige artikler og to bokomtaler dette året. Den andre årgangen handlet om didaktikk generelt, praksis i lærerutdanningen, religionsdidaktikk og språkdidaktikk. Det siste temaet ble omhandlet i hele fem artikler, som til sammen dekket både norsk, engelsk og andre fremmedspråk. Dette var ikke et resultat av en redaksjonell planlegging, men et uttrykk for hvilke manus som ble sendt inn til tidsskriftet og akseptert, og det viste at det var et behov for en publiseringskanal for språkdidaktisk forskning.

I den tredje årgangen ble det fra januar til juni 2009 publisert 8 vitenskapelige artikler og to bokomtaler, like mange som hele det foregående året, noe som tydet på at tidsskriftet var i ferd med å bli kjent. Artikkeltemaene spente fra religions- og naturfagdidaktikk, til samtaler i klasserommet, lærerutdanning, utdanningspolitikk og en artikkel om teknologi og forskningslære, som da var et nytt fag i videregående skole. Hele tre av artiklene hadde lærerutdanning som tema.

I juni 2009 skjedde det endringer i redaksjonen. Else Askerøi ble avløst av June Tolsby, Høgskolen i Akershus som områderedaktør for yrkesfagdidaktikk, og Glenn Ole Hellekjær, ILS tiltrådte som områderedaktør i språkdidaktikk. Rita Hvistendahl takket for seg som ansvarlig redaktør og overlot vervet til Jon Magne Vestøl, ILS. Redaksjonen hadde fram til da sendt 36 artikkelmanus til fagfellevurdering og publisert 22 av dem. I tillegg var flere artikler redaksjonelt vurdert og avvist eller anbefalt omfattende omarbeiding. De fleste artiklene var publisert på norsk, en på svensk, og tre artikler som alle handlet om engelskdidaktikk, ble publisert på engelsk. Til sammen representerte artiklene en fagdidaktisk bredde, og flere artikler hadde lærerutdanning som tema. Alle artiklene var fritt tilgjengelige. Dermed var intensjonene med etableringen av tidsskriftet oppfylt. De norske lærerutdanningsinstitusjonene hadde fått et nytt tidsskrift for publisering av forskningsresultater, og Norge hadde fătt et nytt vitenskapelig tidsskrift med fri tilgang. Open Journal Systems var oversatt til norsk og dermed tilrettelagt for nye tidsskrift.

\section{Konsolideringsfasen 2009-2011}

Redaksjonen for den neste toårsperioden besto av ansvarlig redaktør Jon Magne Vestøl med Therese Nerheim Hopfenbeck som vikarierende redaktør høsten 2010 og redaksjonsleder og layoutredaktør Karl Henrik Flyum, alle fra ILS, i 
tillegg til områderedaktørene Sylvi Penne, June Tolsby og Içara Da Silva Holmesland fra Høgskolen i Oslo og Akershus (HiOA), Erik Knain fra NMBU og Glenn Ole Hellekjær fra ILS.

I denne perioden ble det publisert i alt 17 vitenskapelige artikler. Det språkdidaktiske feltet var sterkest representert, men det var bidrag fra ulike fagdidaktiske felt knyttet til litteratur, historie, matematikk, sang og musikk og kunst og håndverk, i tillegg til mer allmenndidaktiske felt som tilpasset opplæring og samarbeidslæring. Det ble også publisert en egen artikkelgruppe om Kunnskapsløftet.

Tilgangen på manuskripter var jevn, og i overkant av 50 manuskripter ble vurdert. En betydelig andel av disse ble avvist eller trukket fordi de kvalitetsmessig og tematisk ble vurdert å ligge utenfor tidsskriftets fagdidaktiske profil. Det var en tematisk bredde i de artiklene som ble publisert, og en spennvidde blant forfatterne fra professor- til masterstudentnivå. En av artiklene inngikk i en mastergradsavhandling og utgjorde slik sett et forvarsel om bidrag til tidsskriftet fra artikkelbaserte PhD-arbeider.

Årgangen 2010 rommet en nyskapning i form av en artikkelgruppe, det vil si fire artikler og en tilhørende lederartikkel knyttet til temaet Kunnskapsløftet. Arbeidet med artikkelgruppen ble ledet av en setteredaksjon bestående av Sølvi Lillejord, Therese Nerheim Hopfenbeck og Erling Lars Dale. Tematisk dekket artiklene arbeid med grunnleggende ferdigheter, spesialundervisning og tilpasset opplæring og gjennomføring og frafall. Gjennom dette arbeidet høstet tidsskriftet erfaringer som siden ble lagt til grunn i arbeidet med en ny artikkelgruppe høsten 2011 og senere temanummer.

Artikkelgruppen fra 2010 løftet fram mer overgripende pedagogiske aspekter ved læreplanreformer i skolen. Hovedfokus for tidsskriftet var likevel fortsatt å utvikle og styrke tilfanget av fagdidaktiske artikler, både i bredde og kvalitet. Dette ble gjort ved å rekruttere redaksjonsmedlemmer fra ulike fagdidaktiske felt. Samtidig erkjente redaksjonen at spekteret av fagdidaktiske disipliner rommet et mangfold av tradisjoner for vitenskapelig framstilling. Det gjorde det nødvendig å tydeliggjøre normer for det redaksjonelle vurderingsarbeidet og utvikle retningslinjer som kunne formidle disse normene til forfattere og fagkonsulenter. Som ledd i dette arbeidet utviklet redaksjonen retningslinjer for strukturerte sammendrag, som innebar at man kort skulle gjøre rede for artikkelens emne og bakgrunn, material og metode, resultat, drøfting og konklusjon for å sikre leseren innsyn i premissene for den kunnskapsutviklingen som ble presentert i artikkelen.

Parallelt ble det arbeidet med forfatterveiledning. Dette skjedde dels ved at redaksjonen gav særlig fyldige tilbakemeldinger og rettledninger til forfattere som hadde bakgrunn i fagfelt med andre normer for faglig framstilling enn de som redaksjonen nå la til grunn, dels ved at det ble tatt initiativ til forfatterseminar med vitenskapelig ansatte i kvalifiseringsløp for opprykk til førstestillinger. Et slikt seminar ble arrangert ved Høgskolen i Østfold. 
Redaktøren møtte her en gruppe vitenskapelig ansatte og redegjorde for redaksjonelle vurderingsprosesser og vurderingskriterier og kommenterte utkast til arbeider fra deltakerne.

Perioden 2009-2011 var en konsolideringsfase i den forstand at tidsskriftet bekreftet sin berettigelse som en kanal for fagdidaktisk publisering. Samtidig var perioden i en viss forstand en overgangsfase. På den ene siden gav initiativene som ble tatt for å styrke tidsskriftet som en kanal for førstelektorkvalifisering, på lengre sikt få resultater. På den annen side var det i perioden et økende påtrykk for å åpne tidsskriftet for engelskspråklige artikler, blant annet for å imøtekomme behovet for publisering fra doktorgradsstudenter i fagdidaktiske fag. Sammen med publiseringen av artikkelgruppen i 2010 pekte språkendringen framover mot den påfølgende fasen av tidsskriftets historie, da temanummer, konferansenummer og stipendiatbidrag skulle komme til å spille en større rolle.

\section{Ekspansjonsfasen 2012 - 2016}

Fra 2012 til 2016 gikk Acta Didactica Norge gjennom en periode med sterk ekspansjon. Stadig flere sendte inn manuskripter av stadig bedre kvalitet, og antallet utgitte artikler og andre bidrag økte sterkt. Til sammen utga tidsskriftet 131 vitenskapelige artikler og 7 bokomtaler fordelt på fire temautgaver (med 58 vitenskapelige artikler) og seks ordinære utgaver av tidsskriftet (med 73 vitenskapelige artikler). Hele fire av utgavene kom i 2016.

Ansvarlig redaktør i denne perioden var Glenn Ole Hellekjær (ILS). Han overtok også som redaksjonsleder etter Karl Henrik Flyum, mens først Ann Kristin Fiske og deretter Toril Eggen og Sandra Rebekka Nielsen overtok som layoutredaktører. Den kraftige økningen i antall innsendte artikler førte til at redaksjonen gradvis ble utvidet med en rekke nye faste områderedaktører og gjesteredaktører med ansvar for temanummer. Fra ILS beholdt tidligere ansvarlig redaktør Jon Magne Vestøl ansvaret for religionsdidaktikk, mens andre områder og temautgaver ble fulgt opp av Emilia Andersson, Marte BlikstadBalas, Lisbeth Brevik, Joke Dewilde, Britt Oda Fosse, Greta Gudmundsdottir, Kristin Helstad, Frøydis Hertzberg, Ruth Jensen, Jorun Møller og Kari Anne Rødnes. I tillegg deltok Edvin Antonsen, Gerd Johansen og Margrethe Naalsund fra NMBU; Ingvild Digranes fra HiOA; Elin Nesje Vestli, Jane Ekstam og Gerard Doetjes fra Høgskolen i Østfold; Berit Bungum og Lise Kvande fra NTNU; Camilla Erichsen Skalle fra UiB og Per Midthaugen fra Norges Idrettshøgskole.

I 2012 utga tidsskriftet et temanummer med 8 artikler bygd på bidrag fra den internasjonale konferansen Visions for Teaching and Teacher Education: In view of a new knowledge base for Teacher Education, Language Learning and Math/Science Education 2011 arrangert av forskningssatsningen Kunnskap i skolen, Lektorprogrammet ved UiO og ILS. Disse artiklene ble utgitt i samme utgave som 12 andre løpende publiserte artikler. Senere temanumre kom i egne utgaver. Det første av disse, ”Temanummer om engelsk og fremmedspråk. 
Utviklingstrender fram mot 2030", som omfattet 18 artikler, utkom i 2014 og ble redigert av Elin Nesje Vestli ved Høgskolen i Østfold. Deretter ble 2016 et foreløpig høydepunkt med hele to utgaver av løpende publiserte artikler og to temautgaver. Den første temautgaven, "Lærerutdanning i det 21. århundre: tradisjoner, utfordringer, endring", ble redigert av Lisbeth Brevik og Britt Oda Fosse fra ILS og inneholdt 18 artikler fordelt på fire områder: Design av lærerutdanning, Partnerskap i lærerutdanningen, Forholdet mellom vitenskapelige fag og lærerutdanningen og Profesjonsfaglig digital kompetanse.

På høsten kom nok en temautgave, "Skolelederutdanning og ledelsesutvikling i skolen". Den inneholdt 11 artikler, og ble redigert av Kristin Helstad, Ruth Jensen og Jorun Møller fra ILS.

De første årene ble Acta Didactica Norge driftet via en egen server på ILS med liten annen støtte og liten opplæring i bruk av programvaren. Det var derfor en begivenhet da tidsskriftet i 2015 ble innlemmet i FRITT UiO, et samarbeid mellom "Digital Services Department" ved Universitetsbiblioteket, og USIT, som har overtatt ansvaret for driften av Open-access-tidsskrifter ved UiO. Mens USIT drifter serveren som tidsskriftene utgis på, gir Universitetsbiblioteket praktisk støtte til drift av systemet og bruk av programvaren. Universitetsbiblioteket har også hjulpet til med å få tidsskriftet registrert i Directory of Open-Access Journals (DOAJ) og artiklene i tidsskriftet indeksert i den norske utgaven av søkesystemet Oria. Overgangen til FRITT fordret at hele tidsskriftet med alle utgitte artikler måtte flyttes fra serveren på ILS til FRITTserveren hos USIT, et omfattende arbeid som ble utført av dataansvarlig Torgeir Christiansen og layoutredaktør Toril Eggen ved ILS. Som del av overgangen ryddet man også i systemets ulike tekster og reviderte forfatterinstruksen og standardbrevene til forfatterne og fagkonsulentene.

Det tydelige fokuset på norsk fagdidaktisk forskning ved etableringen av tidsskriftet i 2007, førte til en relativt restriktiv bruk av andre språk enn norsk, svensk og dansk. Kun artikler om engelskdidaktikk ble de første årene utgitt på engelsk. Med en økende pågang av artikkelmanus fra forskere og stipendiater som ønsket å skrive på engelsk, ble denne språklige begrensningen stadig mer problematisk. Fra og med 2012-årgangen ble tidsskriftet derfor åpnet for engelskspråklige artikler på alle fagområder, og muligheten til å publisere artikler på både skandinaviske språk og engelsk ser ut til å ha blitt et konkurransefortrinn for tidsskriftet. Med artikler på engelsk, svensk, dansk, bokmål og nynorsk er dagens temanummer et godt eksempel på dette.

Kvaliteten på manuskriptene som sendes inn til Acta Didactica Norge, har variert. Eksempelvis var refusjonsprosenten 55 i 2015 og 39 i 2016, innbefattet refusjon av artikler som ble sendt inn og vurdert flere ganger. For redaksjonen har det ofte vært vanskelig å vurdere i hvilken grad det skulle ytes veiledning og oppfølging til forfatterne under revisjonsarbeidet. Dette gjaldt særlig de første årene etter etableringen av tidsskriftet i 2007. Med den store økningen i antall innsendte artikler ble det tydelig at redaksjonen måtte velge en mer restriktiv 
linje når det gjaldt veiledning av manus. I 2015 ble det derfor utarbeidet en tydeligere forfatterinstruks som krevde at artikler som presenterte nye data, skulle følge IMRaD-strukturen (se for eksempel Publication Manual of American Psychological Association, 6th edition, 25-36), og det ble stilt tydelige krav til formatet på tematiske artikler. I tillegg stilles det nå tydeligere krav til at manus er språkvasket og til konsekvent bruk av referansestil før innsending til fagfellevurdering.

2016 representerte et toppår for tidsskriftet med totalt 53 publiserte fritt tilgjengelige vitenskapelige artikler. Det store artikkelomfanget ble gjort mulig takket være en betydelig utvidelse av redaksjonen, iherdig innsats fra alle redaksjonsmedlemmene og fra en lang rekke fagkonsulenter, stor pågang av manuskript, utgivelse av temanummer og en publiseringsplattform som la til rette for smidig og rask utgivelse. I 2017 overtok Eva Thue Vold som ansvarlig redaktør. Under hennes ledelse blir det en oppgave for redaksjonen å stake ut kursen framover.

\section{Acta Didactica Norge - fra en sped begynnelse til publiseringssuksess}

Ti år etter at Acta Didactica Norge ble etablert i 2007, har tidsskriftet overoppfylt forventningene. Det er publisert 170 vitenskapelige fagfellevurderte artikler fra og med 2007 til og med 2016, og i skrivende stund er det publisert ytterligere 13 artikler i 2017. I perioden 2005-2014 økte antall publiseringspoeng ved norske universiteter og høyskoler med 72 prosent (Kunnskapsdepartementet 2015:94). Økningen fra 39 publiserte artikler i Acta Didactica Norge i den første femårsperioden til 131 artikler i den neste femårsperioden speiler denne utviklingen. Tidsskriftårgangene representerer en stor tematisk bredde innenfor fagdidaktikk og lærerutdanning, og gjennom de mange publiserte artiklene har tidsskriftet bidratt til utviklingen av det fagdidaktiske kunnskapsfeltet. Fagdidaktikk knyttet til de enkelte allmennfagene i skolen er godt representert i tidsskriftet, fagovergripende temaer er representert, og det samme gjelder fagdidaktikk for de praktisk-estetiske fagene og kroppsøvingsfaget. Artikler om fagdidaktikk for yrkesfagene derimot er foreløpig ikke med i tidsskriftet.

Institutt for lærerutdanning og skoleforskning (ILS) tok initiativ til tidsskriftet og har driftet det fra starten i 2007, fra 2015 som del av FRITT $\mathrm{UiO}$, og instituttets ansatte har dominert redaksjonene, men med verdifulle bidrag av medarbeidere fra andre institusjoner. Dette har ikke påvirket ILS' andel av de publiserte artiklene. Med unntak av enkelte temanumre har forskere ved ILS i beskjeden grad benyttet muligheten til å publisere i tidsskriftet. Det har snarere blitt et tidsskrift for vitenskapelig ansatte ved de øvrige norske lærerutdanningsinstitusjonene, og i de siste årgangene har også forskere fra våre naboland markert seg. Ved ILS er vi glad for å ha bidratt til publiseringen ved norske lærerutdanningsinstitusjoner gjennom å utgi et tidsskrift som det er fritt å publisere i. Ved blant annet å utgi flere artikler som inngår i PhD-avhandlinger, 
har tidsskriftet bidratt til kvalifiseringen av norske lærerutdannere. Også ved å tildele redaktøroppdrag og fagfellevurderingsoppgaver har tidsskriftet bidratt til merittering.

Acta Didactica Norge er et fritt tilgjengelig online-tidsskrift. Har det så lykkes i å nå leserne, eller publiseres artiklene mest for forskernes egen merittering? Vi har kun tall fra i år og de to siste årene som kan si noe om dette. I 2015 hadde tidsskriftet 11699 unike nedlastinger, i 2016 økte tallet til 25 827, og hittil i år er tidsskriftet lastet ned 22800 ganger. Tallene forteller ikke i hvilken grad artiklene i tidsskriftet er lest, delvis eller i sin helhet, men de gir en pekepinn på at tidsskriftet leses, og at artiklene når ut.

Vi tre som har vært ansvarlige redaktører for Acta Didactica Norge de ti første årene, og som har skrevet denne oppsummeringen av tidsskriftets korte historie, er takknemlige for å ha fått være med på den eventyrlige utviklingen tidsskriftet har hatt, og for å ha samarbeidet med så mange dyktige bidragsytere.

Vi gratulerer Acta Didactica Norge med tiårsjubileet og ønsker tidsskriftets nye ansvarlige redaktør, Eva Thue Vold, til lykke med arbeidet framover.

\section{Om forfatterne}

Rita Hvistendahl er instituttleder ved Institutt for lærerutdanning og skoleforskning ved Universitetet i Oslo og professor i norskdidaktikk samme sted. Hvistendahl var ansvarlig redaktør for Acta Didactica Norge fra det ble etablert i 2007, til juli 2009.

Institusjonell tilknytning: Institutt for lærerutdanning og skoleforskning, Universitetet i Oslo, Postboks 1099 Blindern.

Epost: r.e.hvistendahl@ils.uio.no

Jon Magne Vestøl er professor i religions- og etikkdidaktikk ved Institutt for lærerutdanning og skoleforskning ved Universitetet i Oslo og studiedekan ved Det utdanningsvitenskapelige fakultet. Vestøl var ansvarlig redaktør for Acta Didactica Norge fra 2009 til 2011 og medlem av redaksjonen fra 2007 til 2013. Institusjonell tilknytning: Institutt for lærerutdanning og skoleforskning, Universitetet i Oslo, Postboks 1099, Blindern

Epost: j.m.vestol@ils.uio.no

Glenn Ole Hellekjær er professor i engelskdidaktikk ved Institutt for lærerutdanning og skoleforskning ved Universitetet i Oslo. Hellekjær var ansvarlig redaktør for Acta Didactica Norge fra 2012 til 2017 og medlem av redaksjonen fra 2009 til 2017.

Institusjonell tilknytning: Institutt for lærerutdanning og skoleforskning, Universitetet i Oslo, Postboks 1099, Blindern

Epost: g.o.hellekjar@ils.uio.no 


\section{Referanser}

Beilstein Journal of Organic Chemistry: Platinum Open Access, https://www.beilstein-journals.org/bjoc/openAccess [Lastet ned 21.9.2017]

ILS 15.03.07. Møteinvitasjon. Arbeidsmøte i Oslo onsdag 18. april 2007, for etablering av det nasjonale vitenskapelige tidsskriftet Acta Didactica Norge. [Offentlig brev. Saksnr. 07/3367/567]

ILS 07.05.07. Kunngjøring og invitasjon: Nytt nasjonalt tidsskrift for fagdidaktikk. [Offentlig brev. Saksnr. 07/3367]

ILS 18.05.07. Erklæring om langsiktig støtte til tidsskriftet Acta Didactica Norge. [Offentlig brev. Saksnr. 07/3367]

ILS 18.05.07. Orientering og anmodning om uttalelse fra NRLU. Rapport fra etableringsmøtet for tidsskriftet Acta Didactica Norge. [Offentlig brev. Saksnr. 07/3367/567]

ILS 01.11.07 Møtereferat. Første møte i Redaksjonsrådet for Acta Didactica Norge. Kunnskapsdepartementet, 2015. Høyere utdanning 2015.

Public Knowledge Project (PKP). Open Journal Systems. https://pkp.sfu.ca/ojs/ [Lastet ned 14.9.2017]

Publication Manual of American Psychological Association, (2010), $6^{\text {th }}$ edition. American Psychological Association: Washington DC, 25-36.

ScienceOPEN.com: Tag: Platinum Open Access http://blog.scienceopen.com/tag/platinum-open-access/ [Lastet ned 21.9.2017]

UHR 2004. Vekt på forskning. Nytt system for dokumentasjon av vitenskapelig publisering. Innstilling fra faglig og teknisk utvalg til UHR.12. november 2004.

Universitetsbiblioteket: FRITT https://journals.uio.no/index.php/index/about/aboutThisPublishingSystem [Lastet ned 21.9.2017] 